\title{
The Effect of Rosemary (Rosmarinus officinalis. L) Plant Extracts on the Immune Response and Lipid Profile in Mice
}

\author{
Fawzi Mohammad Al Sheyab (Correspondence author) \\ Dept. of Biotechnology and Genetic Eng./Jordan University of science and Technology \\ Tel: 962-2-720-1000Ｅ-mail: fawzish@just.edu.jo
}

\begin{abstract}
Nizar Abuharfeil
Dept. of Biotechnology and Genetic Eng./Jordan University of science and Technology Tel: 962-2-720-1000Ｅ-mail: harfeil@just.edu.jo
\end{abstract}

\begin{abstract}
Lina Salloum
Dept. of Biological Sciences/Jordan University of science and Technology

E-mail: lina_salloum@yahoo.com
\end{abstract}

Rehan Bani Hani

Dept of Biotechnology and Genetic Eng./Jordan University of science and Technology

E-mail: rihan_banihani@yahoo.com

Dalal Saleh Awad

Dept of Biological Sciences/Yarmouk University, Irbid, Jordan

E-mail: dalalawad30@hotmail.com

Received: August 28, 2011 Accepted: September 10, 2011

doi:10.5296/jbls.v3i1.906 URL: http://dx.doi.org/10.5296/jbls.v3i1.906 


\section{Abstract}

The hypolipidemic activity of leaves of rosemary (Rosmarinus officinalis), a herbal plant was studied. Three groups of BALB/c mice were treated as following: the first group was fed with normal diet (sugar \& water), the second group was fed with high cholesterol (HC) (2\% by weight) and coconut oil ( $25 \%$ by weight), for 36 days, and the third group was fed with HC diet and given $100 \mathrm{mg} / \mathrm{kg}$ rosemary extract $(10 \% \mathrm{w} / \mathrm{v})$ during the last 15 days of treatment period. There was a significant decrease $(\mathrm{P}<0.001)$ in plasma total cholesterol (TC)($68.57 \%$ ), low density lipoprotein (LDL) (- 56.34\%), and triglycerides (TG) (- 182.61\%). A significant increase in high density lipoprotein (HDL) (38.53\%) was obtained in rosemary-fed mice compared to $\mathrm{HC}$ mice. In another experiment, the immunomodulatory activity of aqueous extract of $R$. officinalis was evaluated in BALB/c mice. Mice were treated with three doses of extract $(10,50,100 \mathrm{mg} / \mathrm{kg}$ body weight) for 8 weeks. Humoral immunity against membrane proteins of sheep erythrocytes measured by ELISA showed that IgM (Immunoglobulin M) response significantly increased by $26.95 \%, 36.5 \%, 70.78 \%$ respectively, in mice fed with 10,50 , and $100 \mathrm{mg} / \mathrm{kg}$ of rosemary as compared to the control group ( $\mathrm{P}<0.05$ ). IgG (Immunoglobulin $\mathrm{G}$ ) response increased significantly at all antibody titers, in mice fed with rosemary at doses of 10,50 , and $100 \mathrm{mg} / \mathrm{kg}$. Meanwhile, there was no significant different in IgM and IgG responses between 50 and $100 \mathrm{mg} / \mathrm{kg}(\mathrm{P}>0.05)$. On the other hand, concanavalin A-stimulated proliferation of spleen cells from mice fed with 100 $\mathrm{mg}$ rosemary extract was significantly higher by $57 \%$ than that of cells from the corresponding control animals.

Keywords: Rosmarinus officinalis, LDL \& HDL cholesterol, Triglycerides, Concanavalin A, Lipopolysaccharises

\section{Introduction}

Vegetable matrices of the Labiatae (Lamiaceae) family such as rosemary have been found to be an important source of substances with antioxidative properties (Oscan ET Al., 2008; Braida ET Al., 2007; Miliauskas ET Al., 2007 \& Wang ET Al., 2008). The lamiaceae is a large family rich in aromatic species that possess essential oils secreted by glandular trichomes (Marin ET Al., 2006). Rosmarinus officinalis L. commonly referred to as rosemary (Oluwatuyi ET Al., 2004) is a plant belonging to Labiatae (Lamiaceae) family (Haloui ET Al., 2000). Rosmarinus officinalis L. is an evergreen, perennial aromatic shrub (Gonzalez ET Al., 2007 \& Orhan ET Al., 2008), reaching a height of $1.5 \mathrm{~m}$ (Atti-Santos ET Al., 2005), native to the chalky, calcareous hills along the Mediterranean Sea (Oluwatuyi ET Al., 2004). It is well known as a common spice and household plant widely used around the world for medicinal purposes. In folk medicine, its aerial parts are used in oral administration to relief renal colic, and dysmenorrhoea and as antispasmodic and antibacterial effect (Orhan ET Al., 2008 \& Soyal ET Al., 2007). The plant has been shown to be safe and non toxic in animal models (Haloui ET Al., 2000 \& Sancheti ET Al., 2006). Because of its powerful antioxidant activity, Rosmarinus officinalis extracts are found to exhibit different protective effects as hepatoprotective, anticancer (Kaliora ET Al., 2005), anti-hyperglycemic (Bakirel ET Al., 2008), asthma and rheumatism (Amin ET Al., 2005). 
The main objective of this investigation is to determine if rosemary extract would lead to immune enhancement of the humoral and cell mediated-immunity, and if this extract would lead to hypolipidemic effect on high cholesterol-fed mice.

\section{Materials and Methods}

\subsection{Plant Material}

Leaves of $R$. officinalis were collected during the spring from the University of Science and Technology garden in Jordan. After collection, the leaves were dried for 15 days in the shade at room temperature. The dried leaves were then ground and stored in the dark.

Water soluble extract was prepared. Briefly the powder $(10 \mathrm{~g})$ was stirred in $100 \mathrm{ml}$ distilled water for 30 minutes at $50 \circ \mathrm{C}$ followed by rapid filtration through a crude cheese cloth and then Wattman No.1 filter paper. The resultant filtrate was lyophilized and then stored at -20 ${ }^{\circ} \mathrm{C}$ in desiccants until used. The yield in $\mathrm{mg}$ was $220 \mathrm{mg}$ (Amin ET Al., 2005).

\subsection{Animals}

The study was conducted on female BALB/c mice 8 weeks old were provided by the Central Animal House Facility of the University of Science and Technology in Jordan. Animals were maintained under standard laboratory conditions (temperature $25 \pm 2{ }^{\circ} \mathrm{C}$; photoperiod of $12 \mathrm{~h}$ ). Prior to each experiment, animals were fasted overnight and allowed free access to water. The experiments were conducted in accordance with the guide for the care and use of lab animals (JUST ANIMAL CARE AND USE COMMITTEE (ACUC)). Commercial pellet diet (8\% Soya,22\% Maize, 6\% Minerals, $4 \%$ Vitamins and 60\% Barely) and water were given ad libitum.

\subsection{Experimental Design}

For lipid profile determination, rosemary extract was administered orally by gavage for 36 days at a dose of $100 \mathrm{mg} / \mathrm{kg}$ body weight. The dose volume was $0.3 \mathrm{ml}$.

Three groups of mice, each of 7 were put in suitable cages and labeled as follows: G1 served as control and received distilled water; G2 was fed with cholesterol (2\% by weight) and coconut oil (25\% by weight) enriched diet; G3 received $100 \mathrm{mg}$ of $R$. officinalis $/ \mathrm{kg}$ by gavage during the last 15 days of treatment period.

For immune response determination, rosemary extract was administered orally by gavage for 8 weeks at doses of $10,50,100 \mathrm{mg} / \mathrm{kg}$ body weight. The dose volume was $0.3 \mathrm{ml}$.

Four groups of mice, each of 10 were put in suitable cages and labeled as follows: G1 served as control and received distilled water; G2 received $10 \mathrm{mg}$ of $R$. officinalis $/ \mathrm{kg}$ by gavage; G3 received $50 \mathrm{mg}$ of $R$. officinalis $/ \mathrm{kg}$ by gavage; and G4 received $100 \mathrm{mg}$ of $R$. officinalis $/ \mathrm{kg}$ by gavage.

\subsection{Lipid Profile}

\subsubsection{Blood samples collection}

At the end of experimental period, mice were fasted for $16 \mathrm{~h}$ and then subjected to light ether 
anaesthesia. Blood samples from cardiac puncture were collected in centrifuge tubes (containing EDTA as an anticoagulant) and centrifuged at $8000 \mathrm{rpm}$ for $10 \mathrm{~min}$ to obtain plasma (Beshbishy ET Al., 2006). Total cholesterol, HDL, LDL and triglycerides were assayed in Plasma using enzymatic kits (Biomerieux, France).

\subsection{The Effect of Rosemary on the Humoral Immune Response}

IgM and $\operatorname{IgG}$ were determined using enzyme linked immunosorbent assay (ELISA) system.

\subsection{Immunization of Mice}

Sheep red blood cells (SRBCs) were obtained from healthy mature sheep maintained in the Animal station of Jordan University of Science and Technology. Blood was collected in equal volume of EDTA tubes. Cells were washed three times in sterile phosphate buffered saline (PBS), and cells were counted by using Improved Cunningham counting chamber before administration and the number of cells was standardized at $1 \times 109 \mathrm{SRBC} / \mathrm{ml}$ (Xiao-Ming ET Al., 2006).

For first immunization, the control and experimental mice were immunized with an intraperitoneal injection of $0.2 \mathrm{ml}$ sheep red blood cell (SRBCs) in PBS with complete adjuvant. Injection of SRBCs as secondary dose with incomplete adjuvant was done three to four weeks after primary injection. Bleeding took place seven to ten days after secondary dose (Liddell ET Al., 1991).

\subsection{Preparation of Hemoglobin-Free Sheep Red Blood Cell Membranes for ELISA}

Briefly, red cells previously washed were lysed by Tris-ethylenediamine tetra acetic acid (EDTA) buffer (0.05 M Tris-HCl, $0.1 \mathrm{mM}$ EDTA, pH 7.6), and centrifuged at 25,100×g for $30 \mathrm{~min}$. The process was repeated until the supernatant was colorless. The membranes were suspended in Tris-EDTA buffer, filtered and resuspended in $0.1 \%$ sodium dodecyl sulfate (SDS) in PBS (with $0.02 \%$ sodium azide). The suspension of membrane antigens was dialyzed for $48 \mathrm{~h}$ against $0.1 \%$ SDS in PBS at room temperature and stored at $4{ }^{\circ} \mathrm{C}$ (Gonzalez ET Al., 2007).

\subsection{Determination of Protein Concentration}

Proteins were quantified by Lowry protein assay (Hudson ET Al., 1989).

\subsection{Enzyme-Linked Immunosorbent Assay (ELISA)}

Microtiter plates were coated with membrane antigen by incubation with $50 \mu 1$ of the antigen suspension in carbonate bicarbonate buffer $(5 \mu \mathrm{g} / \mathrm{ml})$ at $4^{\circ} \mathrm{C}$ overnight. One column in each plate was kept uncoated to serve as a control. Wells were washed with PBS (filling and emptying the wells four times) and then plates were blotted. The plates were incubated with $50 \mu 1$ of blocking buffer, and again washed. Serial dilutions (1:4 for IgM and $\operatorname{IgG})$ of treated and control mouse serum in blocking buffer (PBS containing 1\% BSA (Bovien Serum albumin) and $0.05 \%$ tween-20) was added to each well $(50 \mu \mathrm{l} /$ well $)$ and plates incubated at room temperature. After $1 \mathrm{~h}$ of incubation plates were washed thrice with PBS, and goat anti-mouse $\operatorname{IgM}$ or $\operatorname{IgG}$, at optimal dilution $(1: 1000, \mathrm{v} / \mathrm{v})$ were added to the wells. Following 
incubation for $1 \mathrm{~h}$ at room temperature, the plates were washed thrice with PBS and $50 \mu \mathrm{l}$ of the substrate solution containing $40 \mathrm{mg}$ of OPD (o-phenylenediamine) in citrate buffer and 40 $\mu 1$ hydrogen peroxide $\left(\mathrm{H}_{2} \mathrm{O}_{2}\right)$ was added to each well. Plates were incubated for $10 \mathrm{~min}$. Any color development was stopped by adding $50 \mu \mathrm{l}$ of $1.0 \mathrm{M}$ sulfuric acid to each well. Plates were read at $492 \mathrm{~nm}$ using ELISA reader (Crowther, 2001 \& Bittencourt ET Al., 2007).

\subsection{Colorimetric MTT assay for Con A/LPS-induced splenocyte's proliferation}

Spleens were removed aseptically and homogenized in RPMI 1640 medium supplemented with $10 \%$ heat-inactivated fetal calf serum in the presence of HEPES, antibiotics and glutamine (Sharma ET Al., 2008). The viability of splenocytes was assessed by the trypan blue dye exclusion method (Sahu ET Al,. 1999; Uehara ET Al., 2002). Cells were cultured in 96-well microtiter plates in triplicate, adjusted to a concentration of $5 \times 106$ per well with or without concanavalin A (at a final concentration of $80 \mu \mathrm{g} / \mathrm{ml}$ ), LPS (at a final concentration of $20 \mu \mathrm{g} / \mathrm{ml}$ ), The plates were covered and incubated for $48 \mathrm{~h}$ at $37^{\circ} \mathrm{C}$ in $5 \% \mathrm{CO}_{2}$ incubator with $95 \%$ humidity. Freshly prepared MTT (3-(4,5-dimethylthiazol-2-yl)-2-5-diphenyltetrazolium bromide) $(10 \mathrm{mg} / \mathrm{ml})$ in PBS was added to each well after $44 \mathrm{~h}$. Cultures were incubated for a further $4-6 \mathrm{~h}$ to allow the dye to be metabolized. Solubilization reagent $[(100 \mu 1$ of acidified isopropanol: distilled water (2:1, $\mathrm{v} / \mathrm{v})$ ] was added to each well followed by an overnight incubation at $37^{\circ} \mathrm{C}$ in a $5 \% \mathrm{CO}_{2}$ incubator with $95 \%$ humidity. Data were expressed as absorbance at $570-630 \mathrm{~nm}$, based on the optical wavelengths for differentiating MTT and formazan using a multiple reader (Xiao-Ming ET Al., 2006).

\section{Statistical Analysis}

Antibody primary (IgM) and secondary (IgG) responses to SRBCs and for lymphocyte proliferation assay and lipid profile for each group were analyzed by One Way Analysis of Variance (ANOVA), with post-hoc analysis using Scheffe test for multiple comparisons, with a $\mathrm{P}<0.05$ considered significant. All data was automatically analyzed by computer using SPSS software package.

\section{Results}

\subsection{Plasma Lipid Profile}

The oral administration of $2 \%$ cholesterol in $25 \%$ coconut oil to mice produced a significant increase $(\mathrm{P}<0.001)$ in plasma total cholesterol $(227.65 \%)$, Low Density Lipoprotein cholesterol (LDL-C) (189.35\%) and triglycerides (TG) (232.24\%) as compared to controls, (Figure. 1, 2, 3) while significant reductions ( $<$ 0.001) of plasma HDL-C $(-81.50 \%)$ was found (Figure 4.).

The oral administration of rosemary plant extracts as a $100 \mathrm{mg} / \mathrm{kg}$ per day for 15 days to high cholesterol-fed mice $(\mathrm{HC})$ resulted in significant declines $(\mathrm{P}<0.001)$ in plasma total cholesterol (- 68.57\%), LDL-C (- 56.34\%), and TG (- 182.61\%) as compared to HC mice, while, there was an increase $(38.53 \%)$ in HDL in comparison to HC mice (Table 1). 


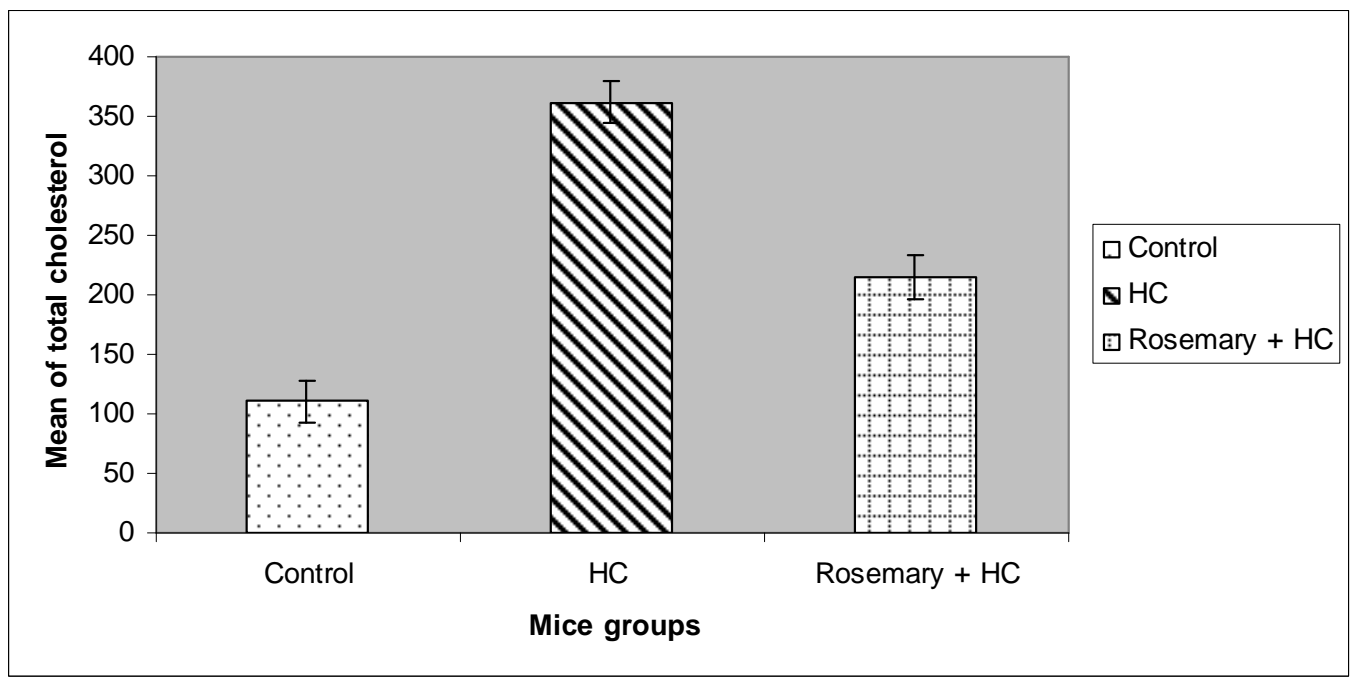

Figure 1 . The effect of oral administration of rosemary plant extract ( $100 \mathrm{mg} / \mathrm{kg}$ body weight) on total cholesterol of high cholesterol-fed mice. Data are expressed as mean \pm SD. Number of mice per group $\mathrm{n}=7$. Statistical significance as compared to the normal control group at $P$ $<0.001 . \mathrm{TC}=$ total cholesterol, $\mathrm{HC}=$ high cholesterol-fed mice

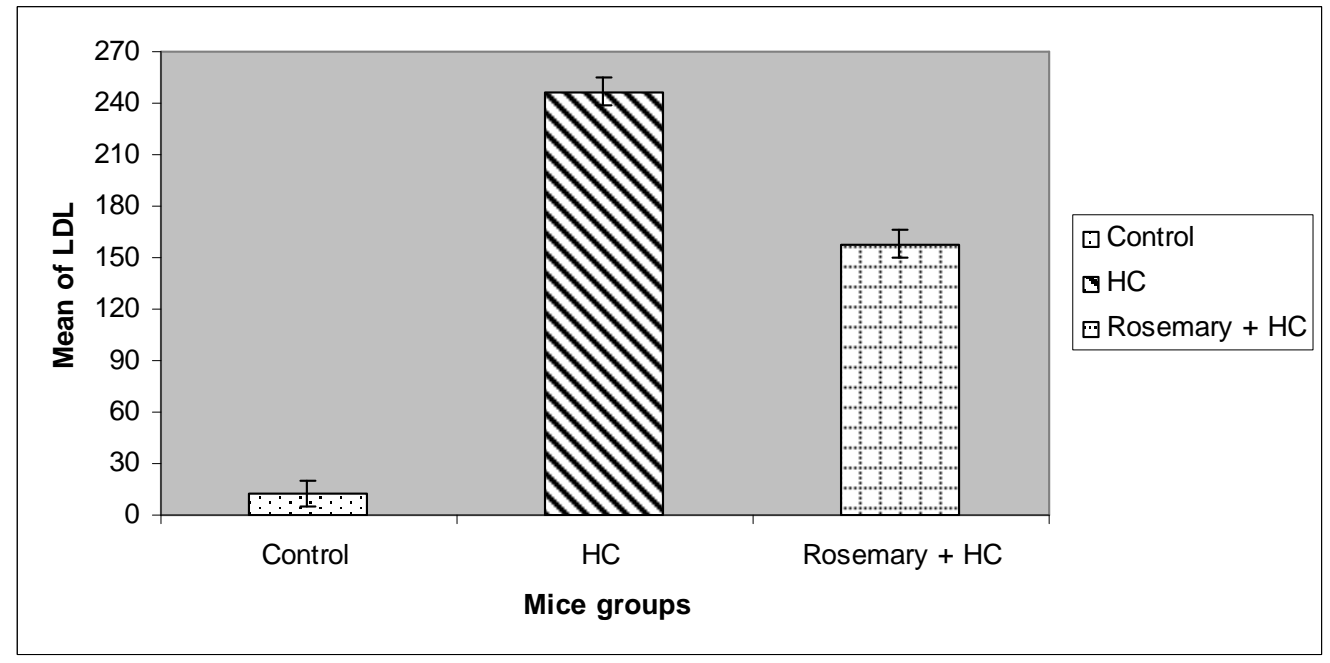

Figure 2. The effect of oral administration of rosemary plant extract (100 mg/kg body weight) on LDL of high cholesterol-fed mice. Data are expressed as mean \pm SD. Number of mice per group $\mathrm{n}=7$. Statistical significance as compared to the normal control group at $P<0.001$. $\mathrm{LDL}=$ low density lipoprotein, $\mathrm{HC}=$ High cholesterol-fed mice 


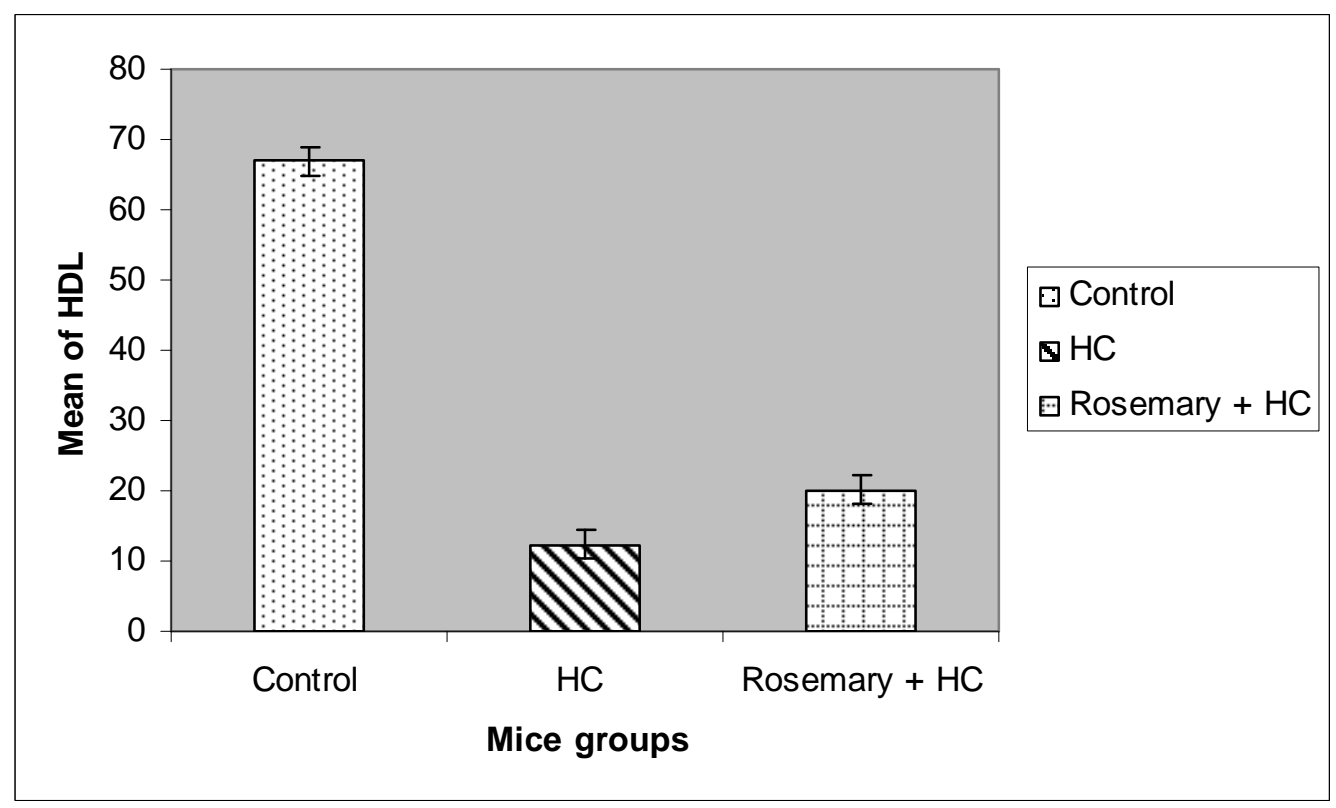

Figure 3. The effect of oral administration of rosemary plant extract (100 mg/kg body weight) on HDL of high cholesterol-fed mice. Data are expressed as mean \pm SD. Number of mice per group $\mathrm{n}=7$. Statistical significance as compared to the normal control group at $P<0.001$. $\mathrm{HDL}=$ high density lipoprotein, $\mathrm{HC}=$ high cholesterol fed- mice

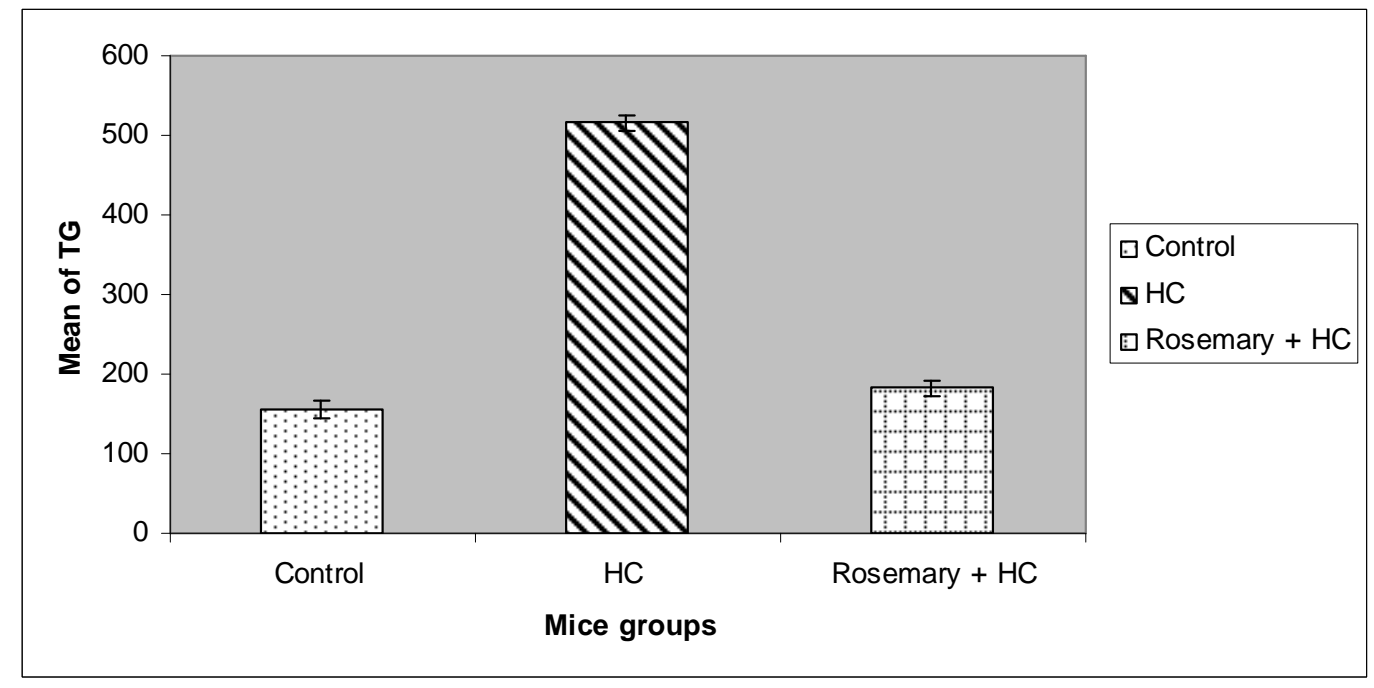

Figure 4. The effect of oral administration of rosemary plant extract (100 $\mathrm{mg} / \mathrm{kg}$ body weight) on TG of high cholesterol-fed mice. Data are expressed as mean \pm SD. Number of mice per group $\mathrm{n}=7$. Statistical significance as compared to the normal control group at $P<0.001$. $\mathrm{TG}=$ triglycerides, $\mathrm{HC}=$ high cholesterol-fed mice 


\section{MInstitute Macrothink $_{\text {Intion }}$}

Journal of Biology and Life Science ISSN 2157-6076 2012, Vol. 3, No. 1

Table 1. The effect of oral administration of rosemary plant extract ( $100 \mathrm{mg} / \mathrm{kg}$ body weight) to high cholesterol-fed mice on TC, LDL, HDL, and TG. Data are expressed as mean \pm SD. Number of mice per group $\mathrm{n}=7 . \mathrm{TC}=$ total cholesterol, $\mathrm{TG}=$ triglycerides, $\mathrm{HDL}=$ high density lipoprotein, $\mathrm{LDL}=$ low density lipoprotein, $\mathrm{HC}=$ high cholesterol-fed mice. $P<$ 0.001

\begin{tabular}{|c|l|l|l|l|}
\hline $\begin{array}{c}\text { Components } \\
(\mathbf{m g} / \mathbf{m l})\end{array}$ & \multicolumn{1}{|c|}{ Control } & \multicolumn{1}{|c|}{ Rosemary } & \multicolumn{1}{|c|}{ HC } & $\begin{array}{l}\text { \% Increase } \\
\text { or decrease }\end{array}$ \\
\hline TC & $110.363 \pm 3.448$ & $214.504 \pm 33.690$ & $361.604 \pm 18.357$ & $-68.57 \%$ \\
\hline TG & $155.297 \pm 2.116$ & $182.560 \pm 41.217$ & $515.958 \pm 27.123$ & $-182.61 \%$ \\
\hline HDL & $66.958 \pm 1.562$ & $20.142 \pm 5.403$ & $12.380 \pm 2.252$ & $38.53 \%$ \\
\hline LDL & $12.376 \pm 2.857$ & $157.739 \pm 29.029$ & $246.601 \pm 22.041$ & $-56.34 \%$ \\
\hline
\end{tabular}

\subsection{The Effect of R. officinalis on the Humoral Immune Response}

Primary antibody response $(\mathrm{IgM})$ to SRBCs was significantly different $(P<0.05)$ in mice pre-treated with rosemary at doses of $10,50,100 \mathrm{mg} / \mathrm{kg}$ body weight as compared to the control mice as shown in figure 5. At antibody titer of 16 and above, significant increase in the total IgM was observed, the percentage increases were $26.95 \%, 36.02 \%$, and $70.78 \%$ for $10,50,100 \mathrm{mg} / \mathrm{kg}$ respectively as compared to the control. There was also a significant one fold increase in the antibody response IgM to SRBCs in mice pre-treated with rosemary at a dose of $50 \mathrm{mg} / \mathrm{kg}$ as compared to mice pre-treated with rosemary at a dose of 10, and two fold for $100 \mathrm{mg} / \mathrm{kg}$ body weight (Table 2), whereas there was no significant difference $(P$ > $0.05)$ between IgM antibody response to SRBCs in mice pre-treated with rosemary at doses of $50 \mathrm{mg} / \mathrm{kg}$ and $100 \mathrm{mg} / \mathrm{kg}$ body weight (Figure5).

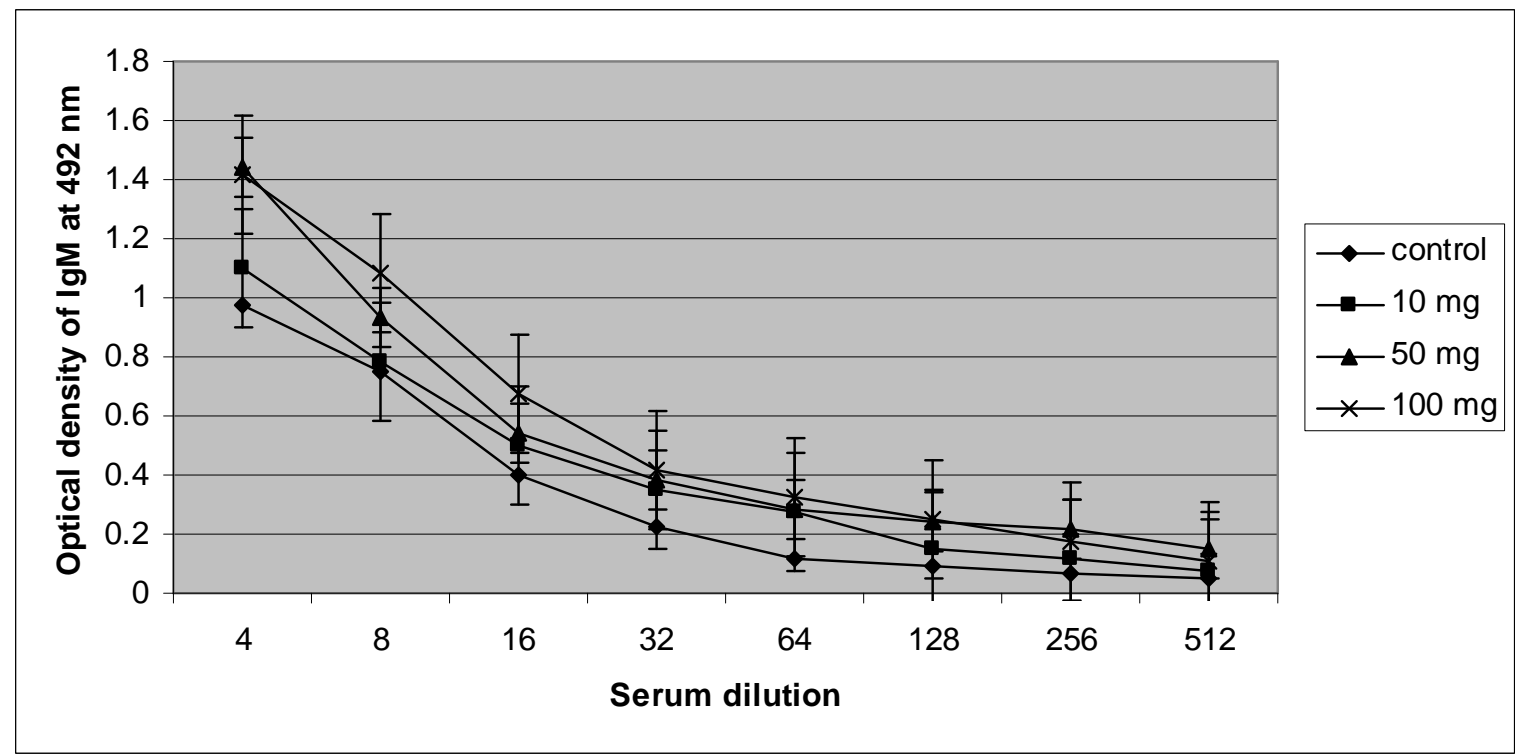

Figure 5. Mean absorbance of total mouse IgM using ELISA assay for control, and rosemary-treated group at different doses 10, 50, $100 \mathrm{mg}$. Number of mice per group $\mathrm{n}=10$. $\mathrm{OD}=$ optical density. $\mathrm{P}<0.05$ between all rosemary doses as compared to control, whereas $P>0.05$ between 50 and $100 \mathrm{mg} / \mathrm{kg}$ of rosemary 
Table 2. Analysis of the humoral immune response to mice immunized with SRBCs on day 7 of treatment of rosemary plant extract. Serum was collected on day 14. Total IgM specific for SRBCs were quantitated as means $\pm \mathrm{SD}$. Number of mice in each group $=10$. $\mathrm{P}<0.05$ between all rosemary doses as compared to control, whereas $\mathrm{P}>0.05$ between 50 and 100 $\mathrm{mg} / \mathrm{kg}$ of rosemary

\begin{tabular}{|c|c|c|c|c|}
\hline \multirow{2}{*}{$\begin{array}{l}\text { Serum } \\
\text { dilution }\end{array}$} & \multicolumn{4}{|c|}{ Rosmarinus officinalis (mg)-fed animals } \\
\hline & $\mathbf{0}$ & $10 \mathrm{mg}$ & $50 \mathrm{mg}$ & $100 \mathrm{mg}$ \\
\hline & \multicolumn{4}{|c|}{ Optical density at $492 \mathrm{~nm}$ wavelength } \\
\hline $1: 4$ & $0.971 \pm 0.511$ & $\begin{array}{c}1.101 \pm 0.471 \\
(13.28 \%)\end{array}$ & $\begin{array}{c}1.440 \pm 0.377 \\
(48.30 \%)\end{array}$ & $\begin{array}{c}1.414 \pm 0.628 \\
(45.21 \%)\end{array}$ \\
\hline $1: 8$ & $0.752 \pm 0.374$ & $\begin{array}{c}0.786 \pm 0.339 \\
(4.52 \%)\end{array}$ & $\begin{array}{c}0.932 \pm 0.223 \\
(23.93 \%)\end{array}$ & $\begin{array}{c}1.083 \pm 0.393 \\
(44.01 \%)\end{array}$ \\
\hline $1: 16$ & $0.397 \pm 0.131$ & $\begin{array}{c}0.504 \pm 0.265 \\
(26.95 \%)\end{array}$ & $\begin{array}{c}0.540 \pm 0.076 \\
(36.02 \%)\end{array}$ & $\begin{array}{c}0.678 \pm 0.185 \\
(70.78 \%)\end{array}$ \\
\hline $1: 32$ & $0.221 \pm 0.068$ & $\begin{array}{c}0.347 \pm 0.198 \\
(57.01 \%)\end{array}$ & $\begin{array}{c}0.385 \pm 0.092 \\
(74.20 \%)\end{array}$ & $\begin{array}{c}0.417 \pm 0.139 \\
(88.68 \%)\end{array}$ \\
\hline $1: 64$ & $0.118 \pm 0.039$ & $\begin{array}{c}0.271 \pm 0.124 \\
(129.66 \%)\end{array}$ & $\begin{array}{c}0.281 \pm 0.042 \\
(138.13 \%)\end{array}$ & $\begin{array}{c}0.328 \pm 0.128 \\
(177.96 \%)\end{array}$ \\
\hline $1: 128$ & $0.090 \pm 0.031$ & $\begin{array}{c}0.152 \pm 0.042 \\
(68.88 \%)\end{array}$ & $\begin{array}{c}0.240 \pm 0.045 \\
(166.66 \%)\end{array}$ & $\begin{array}{c}0.253 \pm 0.073 \\
(181.11 \%)\end{array}$ \\
\hline $1: 256$ & $0.066 \pm 0.030$ & $\begin{array}{c}0.114 \pm 0.022 \\
(72.72 \%) \\
\end{array}$ & $\begin{array}{c}0.216 \pm 0.035 \\
(227.27 \%)\end{array}$ & $\begin{array}{c}0.174 \pm 0.050 \\
(163.63 \%)\end{array}$ \\
\hline $1: 512$ & $0.052 \pm 0.023$ & $\begin{array}{c}0.074 \pm 0.015 \\
(42.30 \%)\end{array}$ & $\begin{array}{c}0.151 \pm 0.050 \\
(190.38 \%)\end{array}$ & $\begin{array}{c}0.108 \pm 0.056 \\
(107.69 \%)\end{array}$ \\
\hline
\end{tabular}

Results obtained with the secondary antibody IgG to SRBCs showed significant elevation of total IgG at all antibody titers starting with 4 and above at all doses of rosemary as compared to the control group $(P<0.05)$ (Figure 6). Maximum increase was observed at 64 antibody titer (384.95\%). Again, there was one fold increase in the antibody IgG response to SRBCs in mice pre-treated with rosemary at a dose of $50 \mathrm{mg} / \mathrm{kg}$ as compared to mice pre-treated with rosemary at a dose of 10, and two fold for $100 \mathrm{mg} / \mathrm{kg}$ body weight (Table 3), and there was no significant difference between mice pre-treated with rosemary at a dose of $50 \mathrm{mg} / \mathrm{kg}$ and mice pre-treated with rosemary at a dose of $100 \mathrm{mg} / \mathrm{kg}$ body weight $(P>0.05)$ (Figure 6). 


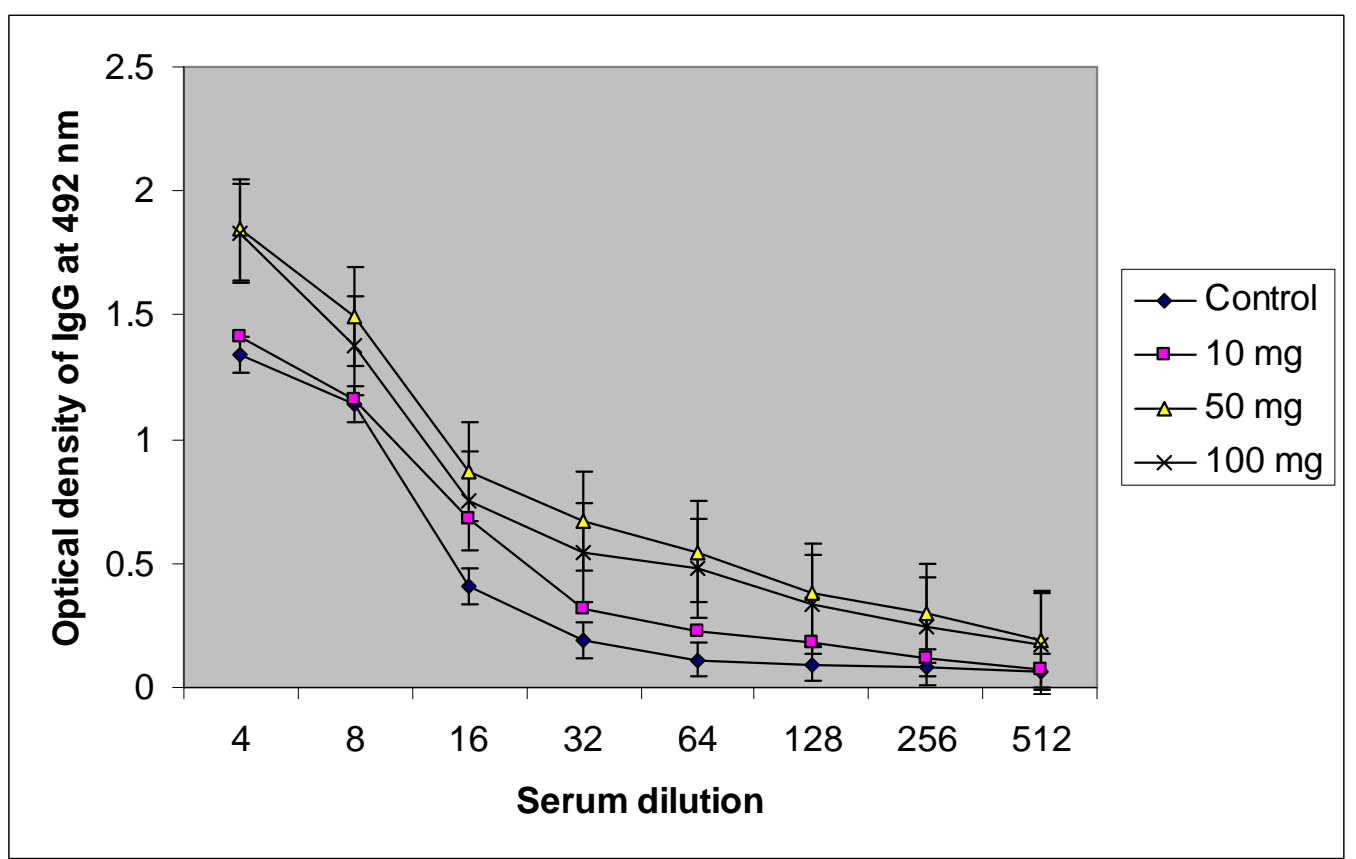

Figure 6. Mean absorbance of total mouse IgG using ELISA assay for control, and rosemary-treated group at different doses 10, 50, $100 \mathrm{mg}$. Number of mice per group $\mathrm{n}=10$. $\mathrm{OD}=$ optical density. $\mathrm{P}<0.05$ between all rosemary doses as compared to control, whereas $P>0.05$ between 50 and $100 \mathrm{mg} / \mathrm{kg}$ of rosemary

Table 3. Analysis of the secondary immune response to mice boosted with SRBCs after three weeks of first immunization. Serum was collected after seven days of secondary immunization. Total IgG specific to SRBCs were expressed as means \pm SD. Number of mice in each group $=10 . \mathrm{P}<0.05$ between all rosemary doses as compared to control, whereas $\mathrm{P}>$ 0.05 between 50 and $100 \mathrm{mg} / \mathrm{kg}$ of rosemary

\begin{tabular}{|c|c|c|c|c|}
\hline \multirow{2}{*}{ Serum dilution } & \multicolumn{4}{|c|}{ Rosmarinus officinalis (mg)-fed animals } \\
\cline { 2 - 5 } & $\mathbf{0}$ & $\mathbf{1 0}$ & $\mathbf{5 0}$ & $\mathbf{1 0 0}$ \\
\hline & & Optical density at 492 wavelength & \\
\hline $1: 4$ & $1.340 \pm 0.362$ & $1.417 \pm 0.381$ & $1.844 \pm 0.167$ & $1.831 \pm 0.307$ \\
& & $(5.74 \%)$ & $(37.61 \%)$ & $(36.64 \%)$ \\
\hline $1: 8$ & $1.143 \pm 0.269$ & $1.160 \pm 0.249$ & $1.497 \pm 0.318$ & $1.375 \pm 0.396$ \\
& & $(1.48 \%)$ & $(30.97 \%)$ & $(20.29 \%)$ \\
\hline $1: 16$ & $0.409 \pm 0.064$ & $0.678 \pm 0.191$ & $0.867 \pm 0.308$ & $0.754 \pm 0.304$ \\
& & $(65.77 \%)$ & $(111.98 \%)$ & $(84.35 \%)$ \\
\hline $1: 32$ & $0.190 \pm 0.044$ & $0.319 \pm 0.119$ & $0.673 \pm 0.171$ & $0.545 \pm 0.194$ \\
& & $(67.89 \%)$ & $(254.21 \%)$ & $(186.84 \%)$ \\
\hline $1: 64$ & $0.113 \pm 0.024$ & $0.230 \pm 0.029$ & $0.548 \pm 0.162$ & $0.477 \pm 0.214$ \\
& & $(103.53 \%)$ & $(384.95 \%)$ & $(322.12 \%)$ \\
\hline $1: 128$ & $0.094 \pm 0.012$ & $0.179 \pm 0.029$ & $0.376 \pm 0.173$ & $0.335 \pm 0.153$ \\
& & $(90.42 \%)$ & $(300 \%)$ & $(256.38 \%)$ \\
\hline $1: 256$ & $0.082 \pm 0.014$ & $0.121 \pm 0.052$ & $0.302 \pm 0.155$ & $0.247 \pm 0.130$ \\
& & $(47.56 \%)$ & $(268.29 \%)$ & $(201.21 \%)$ \\
\hline $1: 512$ & $0.067 \pm 0.024$ & $0.072 \pm 0.051$ & $0.190 \pm 0.109$ & $0.176 \pm 0.084$ \\
& & $(7.46 \%)$ & $(183.58 \%)$ & $(162.68 \%)$ \\
\hline
\end{tabular}




\subsection{Effect of R. officinalis Plant Extract on the Proliferation of Splenic Lymphocytes}

To clarify the biological properties of rosemary, we investigated the mitogenic responses of mouse spleen cells after oral administration of rosemary. Splenocytes obtained from the control group or rosemary-treated group were cultured with or without $\mathrm{T}$ cell mitogen (Con A) or B cell mitogen (LPS). As shown in Figure 7 \& Table 4, the only rosemary treatment that significantly increased (57\%) mitogenic response of spleen cells to Con A was 100 $\mathrm{mg} / \mathrm{kg}$ rosemary extract $(\mathrm{P}<0.05)$. With respect to LPS, there was no significant level at any treatment of rosemary as shown in Figure 8 \& Table 5.

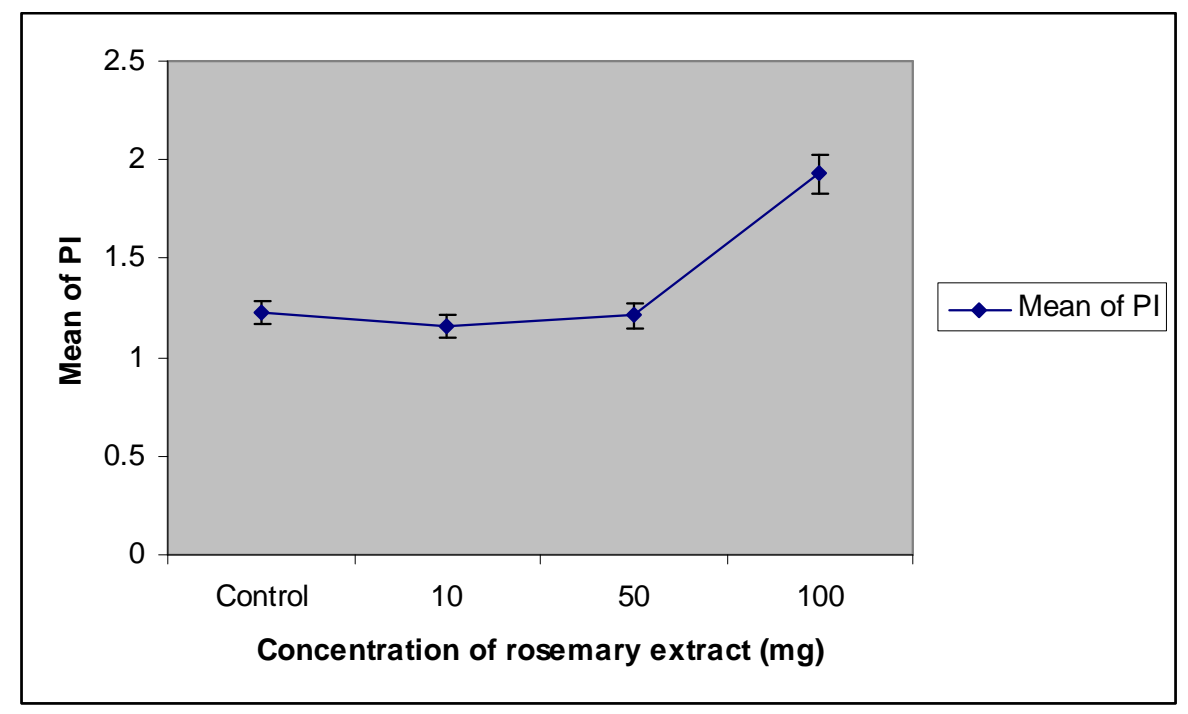

Figure 7. Proliferation assay with Con A mitogen using MTT colorimetric method. Effect of oral administration of rosemary (Rosmarinus officinalis) on the proliferation of mouse splenocytes in response to mitogenic stimulus (Con A). BALB/c mice were administered 0 , $10,50,100 \mathrm{mg}$ of rosemary per kg body weight orally for 8 weeks. The absorbance of the culture was measured at $570 \mathrm{~nm}$. $P<0.05$ as compared to control group. Con A = concanavalin A. $\mathrm{PI}=$ proliferation index $=$ Absorbance of stimulated splenocytes/Absorbance of unstimulated splenocytes

Table 4. Effect of oral administration of rosemary (Rosmarinus officinalis) on the proliferation of mouse splenocytes in response to mitogenic stimulus (Con A). BALB/c mice were administered $0,10,50,100 \mathrm{mg}$ of rosemary per $\mathrm{kg}$ body weight orally for 8 weeks. The data represent the mean \pm SD of PI of triplicate wells. Number of mice for each group $=10$. Con $\mathrm{A}=$ concanavalin $\mathrm{A}$. $\mathrm{PI}=$ proliferation index. $\mathrm{PI}=$ Absorbance of stimulated splenocytes/ Absorbance of unstimulated splenocytes. $P<0.05$

\begin{tabular}{|l|l|}
\hline Groups & Proliferation index (PI) \\
\hline Control & $1.227 \pm 1.546$ \\
\hline $10 \mathrm{mg}$ rosemary & $1.153 \pm 1.395$ \\
\hline $50 \mathrm{mg}$ rosemary & $1.210 \pm 0.203$ \\
\hline $100 \mathrm{mg}$ rosemary & $1.930 \pm 0.574$ \\
\hline
\end{tabular}




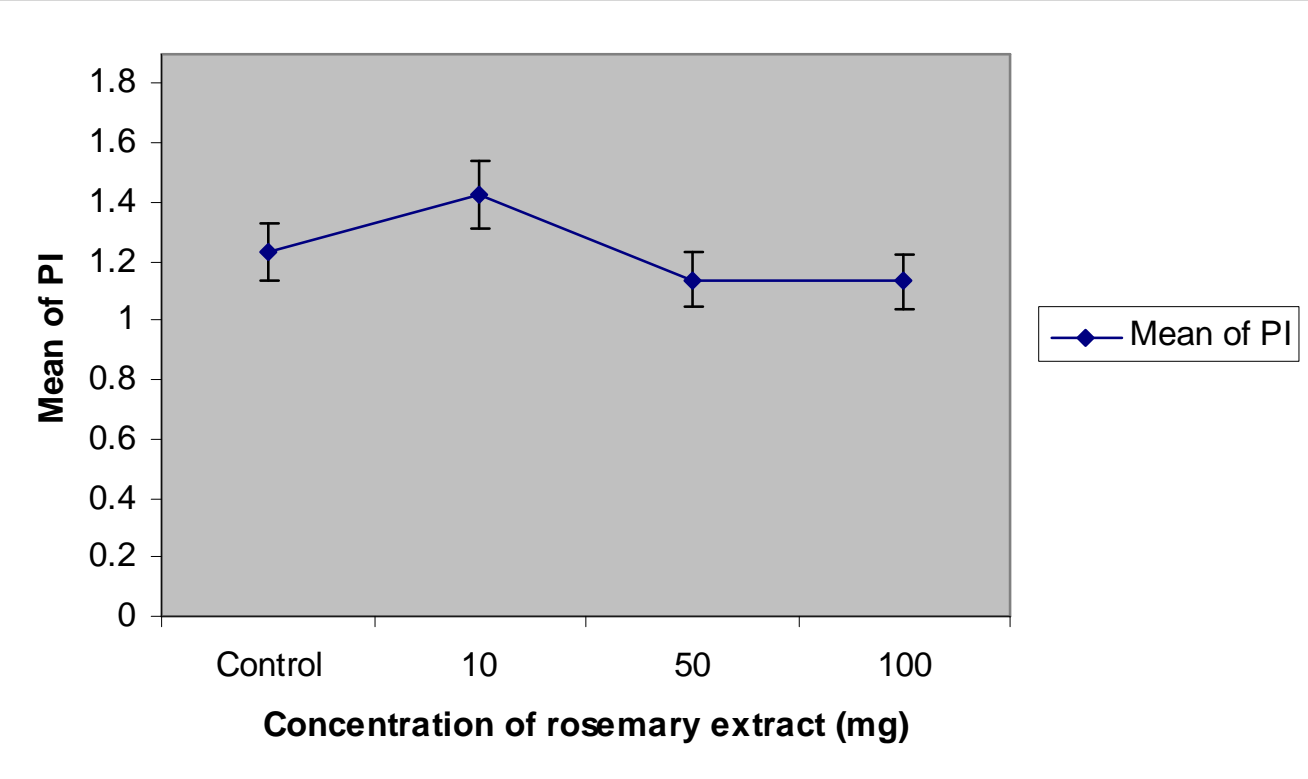

Figure 8. Proliferation assay with LPS mitogen using MTT colorimetric method. Effect of oral administration of rosemary (Rosmarinus officinalis) on the proliferation of mouse splenocytes in response to mitogenic stimulus (LPS). BALB/c mice were administered 0, 10, $50,100 \mathrm{mg}$ of rosemary per $\mathrm{kg}$ body weight orally for 8 weeks. The absorbance of the culture was measured at $570 \mathrm{~nm} . P>0.05$ as compared to control group. LPS $=$ lipopolysaccharide. PI $=$ proliferation index, $\mathrm{PI}=$ Absorbance of stimulated splenocytes/ Absorbance of unstimulated splenocytes

Table 5. Effect of oral administration of rosemary (Rosmarinus officinalis) on the proliferation of mouse splenocytes in response to mitogenic stimulus (LPS). BALB/c mice were administered $0,10,50,100 \mathrm{mg}$ of rosemary per $\mathrm{kg}$ body weight orally for 8 weeks. The data represent the mean \pm SD of PI of triplicate wells. Number of mice for each group $=10$. LPS = lipopolysaccharide. $\mathrm{PI}=$ proliferation index. $\mathrm{PI}=$ Absorbance of stimulated splenocytes/ Absorbance of unstimulated splenocytes. $P>0.05$

\begin{tabular}{|c|c|c|c|c|c|}
\hline Groups & PI & \multicolumn{2}{|c|}{ ANOVA } & F value & Significance \\
\hline Control & $1.232 \pm 1.306$ & $\begin{array}{l}\text { Between } \\
\text { groups }\end{array}$ & $\begin{array}{l}\text { Within } \\
\text { groups }\end{array}$ & \multirow[t]{4}{*}{1.663} & \multirow[t]{4}{*}{0.220} \\
\hline $10 \mathrm{mg}$ rosemary & $1.424 \pm 0.205$ & \multirow[t]{3}{*}{0.196} & \multirow[t]{3}{*}{0.549} & & \\
\hline $50 \mathrm{mg}$ rosemary & $1.132 \pm 0.091$ & & & & \\
\hline $100 \mathrm{mg}$ rosemary & $1.137 \pm 0.057$ & & & & \\
\hline
\end{tabular}

\section{Discussion}

This study demonstrated clearly the hypolipidemic activity of $R$. officinalis species. The lipid profile (TC, HDL, LDL and TG) showed significant reduction [TC (68.57\%), LDL (56.34\%), and TG (182.61\%)] in rosemary-fed mice as compared to the HC mice. On the other hand, significant elevation $(38.53 \%)$ of the HDL was observed in rosemary-fed mice as compared to the $\mathrm{HC}$ mice. In this study, high cholesterol was induced in mice by adding cholesterol (2\%) and coconut oil (25\%) to the diet for 36 days. This finding is in agreement with other 
investigators who support that high fat diet resulted in hypercholesterolemia such as significant increase in plasma total cholesterol, LDL-C, triglycerides and hepatic oxidative damage (Berrougui ET Al., 2003, Harnafi ET Al., 2007 \& Rui ET Al., 2008). Furthermore, these results are in close agreement with previous study carried out in animals fed with fats, in which the hypercholesterolemic effect was attributed to saturated fatty acids occurring in coconut oil (Uehara ET Al., 2002 \& Garcia-Fuentes ET Al., 2002). Myristic and lauric acids, present mainly in coconut oil, appear to be the main saturated fatty acids that raise plasma cholesterol, increasing LDL more than HDL fraction. Coconut oil consumption has appeared to encourage the incorporation of saturated fatty acids into the LDL receptor membrane and, ultimately, inhibiting its function (Garcia-Fuentes ET Al., 2002). The high levels of LDL-C found in $\mathrm{HC}$ mice may be due to changes in hepatic LDL receptor that contribute to the elevation in blood cholesterol levels induced by high-cholesterol diets and it has been established that cholesterol rich diets increased LDL-C levels in blood and cause oxidative stress that results in increased oxidized LDL levels (Quing-Feng ET Al., 2008 ).

This study also corroborates with another study that showed significant inhibitory effect of sage on serum TG elevation in olive-loaded mice, and inhibitory activity against pancreatic lipase, which participates in digestion of lipids (Ninomiya ET Al., 2004).

Measurement of the total polyphenolic content of some species of the Lamiaceae family, using the Folin Ciocalteau method revealed the presence of $132.6 \mu \mathrm{g} / 100 \mu \mathrm{L}$ in the Mentha piperita extract, $48 \mu \mathrm{g} / 100 \mu \mathrm{L}$ in the Rosmarinus officinalis extract, and $38 \mu \mathrm{g} / 100 \mu \mathrm{L}$ in the Siderites clandestina extract (Kaliora ET Al.,2005). Because the protective activity revealed the same order of magnitude as the polyphenolic content, the amount of polyphenols could be correlated directly with their in vitro effect (Kaliora ET Al.,2005). Additionally, an in vitro experiment conducted in reconstituted planer lipid bilayers confirmed the ability of some polyphenols (e.g. flavonoids) to penetrate the lipid membranes constituted with phospholipids (Gladine ET Al.,2007). In fact, ubiquitous plant polyphenols such as flavonoids, have exhibited a variety of pharmacological activities, including the anti-atherogenesis effect, and their role in prevention of coronary heart disease including atherosclerosis (Harnafi, ET Al.,2007), and have been demonstrated to inhibit lipid peroxidation, and increasing glutathione peroxidase concentrations that have been shown to play a protective role against oxidative damage in various tissues by neutralizing reactive oxygen species (Wellwood ET $A l ., 2004$ \& Olaleye ET Al.,2008). Further, several authors have also reported that flavonoids have hypolipidemic and hypocholesteromic effects (Sharma ET Al., 2008). Another study has shown that flavonoids could reduce oxidized LDL in human and make LDL less susceptible to oxidative stress, and also flavonoids could recycle $\alpha$-tocopherol by donating a hydrogen atom to the $\alpha$-tocopherol radical, and thereby, delay the onset of lipid peroxidation. Therefore, Rosmarinus officinalis L. plant extracts have the ability to decompose free radicals by quenching active singlet oxygen and by trapping and quenching radicals before they reach a cellular target (Moreira ET Al., 2005). The increase HDL-C concentration could protect the LDL against oxidation in vivo because lipids in HDL are preferentially oxidized before those in LDL (El-Beshbishy ET Al., 2006).

Hypercholesterolemia or more specifically elevated plasma LDL-cholesterol is an important 
risk factor for development and progression of atherosclerosis (Harnafi ET Al., 2007) which is accompanied by the production of free radicals by endothelial and vascular smooth muscles. These free radicals initiate processes involved in atherogenesis through several important enzyme systems, including xanthine oxidase, nicotinamide adenine dinucleotide phosphaste (NADP), oxidases and nitric oxide synthase. Hypercholesterolemia state leads to an increase in free radical production and thereby elevates lipid peroxides (El-Beshbishy ET Al., 2006).

Substantial evidence has shown that lowering total cholesterol and LDL levels reduces the incidence of coronary heart disease (CHD), (Miller ET Al., 2006). Attempts to decrease plasma cholesterol by diet, drugs or certain plants which contain a wide array of free radical scavenging molecules, such as flavonoids that have antioxidant and hypolipidemic activities are based on the hope that reduction in the rates of deposition of cholesterol may decrease both sizes of the lesions as well as the risk of myocardial infraction (El-Beshbishy ET Al., 2006). For further support of our data regarding lipid plasma, further investigations were reported that rosemary could induce xenobiotic detoxification enzymes in rat liver (Amin ET $A l ., 2005)$. Another study showed that plants belonging to the Lamiaceae family are very rich in polyphenolic compounds, and due to theses compounds they exhibit antioxidant properties (Lee ET Al., 2008). Oxidative stress, resulting from these metabolic reactions that use oxygen, has been implicated in human disease by a growing body of factors. LDL is particularly susceptible to oxidative stress and the resulting oxidized LDL is implicated in fatty streak formation and initiation of atherosclerosis (Kaliora ET Al., 2005). Extracts of Rosmarinus officinalis L. were evaluated for their antioxidant effects via the inhibition of lipid oxidation (Bragagnolo ET Al., 2005 \& Albu ET Al., 2004).

To be able to scavenge lipid radicals formed within the lipoprotein particles, the active components of plant extracts should be able to be incorporated into the LDL particles, at least to some extent (Dorman ET Al., 2003). The evaluation of antioxidants depends on measuring their ability either to scavenge free radicals or to inhibit the oxidative rancidity (Wellwood $E T$ Al., 2004 \& Sotelo-Felix ET Al., 2004). Lipid oxidation is characterized by three stages: initiation (forming lipid radicals); propagation via peroxides (forming hydrogen peroxides); and termination (mainly by the decomposition of hydroperoxides) (Wellwood ET Al., 2004). Rosemary antioxidants interrupt lipid oxidation either in the propagation phase (Bragagnolo ET Al., 2007 \& Albu ET Al., 2004) by a chain-breaking mechanism or give protection of the oxidation substrates against the first formed radicals in the initiation phase. These effects may be attributed to the presence of high percents of antioxidant compounds in Rosmarinus officinalis water extract. It has been shown that Rosmarinus officinalis water extract and its antioxidant compounds inhibit lipid peroxidations and free radicals generation in vitro and in vivo. Rosmarinic acid, diterpenoids and alpha-tocopherol have been documented as the principal antioxidant constituents of rosemary extract (Amin ET Al., 2005). The active compounds of rosemary extracts are mainly phenolic compounds, which belong to three groups: phenolic diterpenes, flavonoids and phenolic acids. Carnosic acid (CA) which is the major phenolic diterpene present in rosemary leaves (Wellwood ET Al., 2004), and carnosol, both of which have been suggested to account for over $90 \%$ of the antioxidant properties of 
rosemary extract (Lemonica ET Al., 1996 \& Lo ET Al., 2001), and rosmarinic acid, rosmanol, a hydroxyl cinnamic acid ester, are the main antioxidant compounds present in rosemary. These compounds, together with other isoprenoids (sterol, isoprene, mono and diterpenes, tocopherols and carotenoids) are considered as anti-inflammatory agents (Perez ET Al., 2007, Tawaha ET Al., 2007, Almela ET Al., 2006 \& Luis ET Al., 2007). Other compounds present in rosemary are the essential oils such as camphor, cineole, $\alpha$-pinene, borneol which are largely used in traditional medicine, in perfumery and have also antimicrobial activity (Marzouk ET Al., 2006, Weckessera ET Al., 2007, Gillij ET Al., 2008 \& Zaouali ET Al., 2008). In conclusion, we have found that extracts of $R$. offcinalis possesses significant hypolipidemic potential.

Rosemary has been commonly used against asthma, eczema and rheumatism. Its antimammary tumorigenesis effect is also well established (Amin ET Al., 2005). In the present study, rosemary showed stimulatory effect on some parameters of the immune functions in mice. We studied the effect of rosemary on the primary and secondary antibody responses, when mice were immunized with SRBCs, and as obtained from the results, there was evidence, in the anti-SRBCs response data presented that the dose-response for the three treated groups was significantly different from the control group $(P<0.05)$ (fig 5,6) and there was also a significant difference between mice pre-treated with rosemary at a dose of 50 or $100 \mathrm{mg} / \mathrm{kg}$ compared to mice pre-treated with rosemary at a dose of $10 \mathrm{mg} / \mathrm{kg}$ body weight. These results support that several active principles of rosemary such as flavonoids, saponosids or organic acids may enhance SRBCs to bind to B-memory cells, stimulating them to differentiate into antibody-secreting plasma cells and thereby enhancing secondary antibody responses. Another study showed that rosmarinic acid has anti-inflammatory activities in vivo including suppression of endotoxin-induced complement activation and shock (Sahu ET Al., 1999). In addition, at $10 \mathrm{mg} / \mathrm{kg}$ i.m. rosmarinic acid isolated from rosemary or melissa impaired in vivo activation by heat-killed Corynebacterium parvum (i.p.) of mouse macrophages (Englberger ET Al., 1988). Most of the plants so far reported for immunomodulatory effects such as ginseng or Salvia extract increased the levels of influenza virus specific antibodies and neutralizing activities (Quan ET Al., 2007).

On the other hand there was no evidence that primary $\operatorname{IgM}$ or secondary $\operatorname{IgG}$ antibody response to SRBCs was significantly different in mice pre-treated with rosemary at a dose of $50 \mathrm{mg} / \mathrm{kg}$ and $100 \mathrm{mg} / \mathrm{kg}$ body weight $(P>0.05)$. In the humoral immunity, $50 \mathrm{mg} / \mathrm{kg}$ dose was most effective in inducing the antibody response. It appears that $50 \mathrm{mg} / \mathrm{kg}$ might be the optimum dose in mice. Although there was no immunosuppression by $100 \mathrm{mg} / \mathrm{kg}$ rosemary extract compared to the control group, immune response in this group was lower than that in the $50 \mathrm{mg} / \mathrm{kg}$ rosemary group. Thus, the inability of rosemary at a dose of $100 \mathrm{mg} / \mathrm{kg}$ to cause immunoenhancement more than a dose of $50 \mathrm{mg} / \mathrm{kg}$ may have been due to an increase in dietary rosemary which may have caused an immunosuppression, as suggested by another study, in which i.p. injections of $40 \mathrm{IU}$ vitamin $\mathrm{E} / \mathrm{kg} /$ day $/$ mouse resulted in immunosuppression (Babu ET Al., 1998), or increase in dose might have induced downregulation of the immune functions, or might have induced some hormones such as cortisol. The humoral immune response can be measured as an increase in levels of total antibodies or 
of specific antibodies against a non-pathogenic antigen such as SRBCs. The level of a specific antibody in the serum can also be used as a measure of the functional status of all three development phases of humoral immune response- antigen recognition, activation and expression (Martinez ET Al., 2001). The integrity of the antibody mediated (humoral) immune response depends upon a competent population of B lymphocytes which have the functional capacity to develop into antibody-producing plasma cells. Interpretation of the antibody response to SRBCs is complicated by the fact that blood cells are antigenically complex. Blood cells express hundreds of possible antigens against which vaccinated animals may be responding. Animals can make antibodies against foreign blood cells. These preexisting, or natural antibodies are not derived from prior contact with foreign RBC, but result from exposure to similar or identical epitopes that commonly occur in nature (Smits ET Al., 2001). Because of the antigenic complexicity of SRBCs, it is not known against which particular antigen(s) the antibodies are being raised. Therefore, ELISA method was used to detect specific antibodies produced against certain antigens (Martinez ET Al., 2001).

The mitogen-stimulated response is an in vitro correlate of activation and proliferation of specifically sensitized lymphocytes by antigen in vivo. The mitogen-stimulated response has been used to assess the immunotoxic potential of drugs and chemicals in humans and experimental animals. Con $\mathrm{A}$ is a special $\mathrm{T}$ lymphocyte mitogen which is derived from the jack bean Concanavalia enciformis. In addition to plant lectins, a wide variety of chemically diverse agents have been demonstrated to be mitogenic for cultured lymphocytes. These include bacterial products such as lipopolysaccharides (LPS) from gram-negative bacteria, which is a special B lymphocyte mitogen (Burleson ET Al., 1995). The assay of Con A induced $\mathrm{T}$ lymphocyte and LPS-induced B lymphocyte proliferation were used for assessment of the effects of chemical on the T and B lymphocyte activities, respectively (Hou ET Al., 2007). The MTT assay was used to measure the survival lymphocyte activity after proliferation by a colorimetric method based on the tetrazolium salt (Hou ET Al., 2007). In this study, the effect of rosemary extract on Con A and LPS- mediated proliferation of splenic lymphocytes was assessed. Mitogenic response represents a late event in T-cell activation, namely DNA synthesis (Babu ET Al., 1998). The results only showed that $100 \mathrm{mg} / \mathrm{kg}$ rosemary had induced significant increases in Con A-induced T- cell proliferation, whereas the other lower doses of rosemary had no significant effect.

In this study, the dose of $100 \mathrm{mg} / \mathrm{kg}$ rosemary might be ideal to generate a response in splenocytes better than that observed in the control group. On the other hand the effect of rosemary on B cell proliferation can be conducted using LPS, since the spleen is an important organ, which contains mainly B-lymphocytes. Hence, the spleen can indirectly reflect humoral immunity (Xiao-Ming ET Al., 2006). Our data demonstrated that administration of rosemary had no significant increase on LPS-induced B cell proliferation. Rosemary could enhance or activate the secretion of immunoglobulins such as IgM and IgG without affecting B cells proliferation. This study was compatible with another study that assumed the inhibitory effect of some components of rosemary such as carnosol and carnosic acid on LPSinduced nitric oxide production (Lo ET Al., 2002). These results are in agreement with another study which showed that rosemary which has been used as food additive and as 
dietary supplement because of its powerful antioxidant activity (Dorman ET Al., 2003) may function as an immunoenhancing antioxidant that could help alleviate the oxidative stress condition and will probably be effective in some stressed condition such as protein or antioxidant deficiency (Babu ET Al., 1998).

Further investigation should target understanding the mechanism of increased mitogen response by $100 \mathrm{mg} / \mathrm{kg}$, and adjusting the ideal dose of rosemary that have stimulatory effects on some parameters of the immune function in mice. Its reported immunomodulatory effects warrant further investigation for its use in cases of clinical immunosuppression, and the determination of the active constituents of rosemary that have the hypolipidemic effect and the stimulatory effect on some parameters of the immune response would be urgently required.

\section{References}

Albu S, Joyce E, Paniwnyk L, Lorimer JP, \& Mason TJ. (2004). Potential for the use of ultrasound in the extraction of antioxidants from Rosmarinus officinalis for the food and pharmaceutical industry. Ultrasonics Sonochemistry, 11: 261-265. http://dx.doi.org/10.1016/j.ultsonch.2004.01.015

Almela L, Sanchez-Munoz B, Fernandez-Lopez JA, Rocca MJ, \& Rabea V. (2006). Liquid chromatographic-mass spectrometric analysis of phenolics and free radical scavenging activity of rosemary extract from different raw material. Journal of Chromatography, 1120: 221-229. http://dx.doi.org/10.1016/j.chroma.2006.02.056

Amin A \& Hamza AA. (2005). Hepatoprotective effects of Hibiscus, Rosmrinus and Salvia on azathioprine-induced toxicity in rats. Life Sciences, 77: 266-278. http://dx.doi.org/10.1016/j.lfs.2004.09.048

Atti-Santos AC, Rossato M, Pauletti GF, Rota LD, Rech JC, Pansera MR, Agostini F, Serafini LA, \& Moyna P. (2005). Physico-chemical evaluation of Rosmarinus officinalis L. essential oils. Brazilian Archives of Biology and technology, 48 (6): 1035-1039. http://dx.doi.org/10.1590/S1516-89132005000800020

Babu US, Wiesenfeld PL, \& Jenkins MY. (1998). Effect of dietary rosemary extract on cell-mediated immunity of young rats. Plant Foods for Human Nutrition, 53:_169-174. http://dx.doi.org/10.1023/A:1008040324935

Bakirel T, Bakirel U, Keles OU, Ulgen SG, \& Yardibi H. (2008). In vivo assessment of antidiabetic and antioxidant activities of rosemary (Rosmarinus officinalis) in alloxan-diabetic rabbits. Journal of Ethnopharmacology, 116: 64-73. http://dx.doi.org/10.1016/j.jep.2007.10.039

Berrougui H, Ettaib A, Gonzales MDH, de Sotomayor MA, Bennani-Kabchi N, \& Hmamouchi M. (2003). Hypolipidemic and hypocholesterolemic effect of argan oil (Argania spinosa L.) IN Meriones shawi rats. Journal of Ethnopharmacology, 89: 15-18. http://dx.doi.org/10.1016/S0378-8741(03)00176-4 
Bittencourt CS, Azzolini AECS, Ferreira DA, \& Assis-Pandochi AI. (2007). Antibody response in hyperthyroid rats. International Imminopharmacology, 7: 989-993. http://dx.doi.org/10.1016/j.intimp.2007.02.016

Bragagnolo N, Danielsen B, \& Skibsted LH. (2007). Rosemary as antioxidant in pressure processed chicken during subsequent cooking as evaluated by electron spin resonance spectroscopy. Innovative Food Science and Emerging Technologies, 8: 24-29. http://dx.doi.org/10.1016/j.ifset.2006.04.005

Bragagnolo N, Danielsen B, \& Skibsted LH. (2007). Rosemary as antioxidant in pressure processed chicken during subsequent cooking as evaluated by electron spin resonance spectroscopy. Innovative Food Science and Emerging Technologies, 8: 24-29. http://dx.doi.org/10.1016/j.ifset.2006.04.005

Braida I, Mattea M, \& Cardarelli D. (2007). Extraction-adsorption-desorption process under supercritical condition as a method to concentrate antioxidants from natural sources. Journal of Supercritical Fluids, 45 (2): 195-199. http://dx.doi.org/10.1016/j.supflu.2007.08.013

Burleson GR, Dean JH, \& Munson AE. (1995). Methods in immunotoxicology. Volume 1. John Wilely \& Sons, Inc. New York.

Crowther JRI. (2001). Enzyme-linked immunosorbent assay. Method in molecular biology, vol 149. Human Press Inc. Totowa, NJ.

Dorman HJD, Peltoketo A, Hiltunen R, \& Tikkanen MJ. (2003). Characterization of the antioxidant properties of de-odorized aqueous extracts from selected Lamiaceae herbs. Food Chemistry, 83: 255-262. http://dx.doi.org/10.1016/S0308-8146(03)00088-8

El-Beshbishy HA, Singab ANB, Sinkkonen J, \& Pihlaja K. (2006). Hypolipidemic and antioxidant effects of Morus alba L. (Egyptian mulberry) root bark fraction supplementation in cholesterol-fed rats. Life Science, 78: 2724-2733. http://dx.doi.org/10.1016/j.lfs.2005.10.010

Englberger W, Hadding U, Etschenberg E, Graf E, Leyck S, Winkelmann J, \& Parnham MJ. (1998). Rosmarinic acid: a new inhibitor of complement C3-convertase with anti-inflammatory activity. International Journal of Immunopharmacology, 10 (6): 729-737. http://dx.doi.org/10.1016/0192-0561(88)90026-4

Garcia-Fuentes E, Gil-Villarino A, Zafra MF, \& Garcia-Peregrin E. (2002). Dipyridamole reduces cholesterol and lipoproteins from young chicks fed a saturated fat-enriched diet. Environmental Toxicology and pharmacology, 11: 39-47. http://dx.doi.org/10.1016/S1382-6689(01)00105-3

Gillij YG, Gleiser RM, \& Zygadlo JA. (2008). Mosquito repellent activity of essential oils of aromatic plants growing in Argentina. Bioresource Technology, 99: 2507-2515. http://dx.doi.org/10.1016/j.biortech.2007.04.066

Gladine C, Morand C, Rock E, Bauchart D, \& Durand D. (2007). Plant extracts rich in polyphenols (PERP) are efficient antioxidants to prevent lipoperoxidation in plasma lipids 
from animals fed n - 3 PUFA supplemented diets. Animal feed Science and Technology, 136 (3): 281-296. http://dx.doi.org/10.1016/j.anifeedsci.2006.09.003

Gonzalez-Trujano ME, Pena EI, Martinez AL, Morenoa J, Guevara-Fefer P, Deciga-Campos M, \& Lopez-Munoz FJ. (2007). Evaluation of the antinociceptive effect of Rosmarinus officinalis L. using three different experimental models in rodents. Journal of Ethnopharmacology, 111: 476-482. http://dx.doi.org/10.1016/j.jep.2006.12.011

Haloui M, Louedec L, Jean-Baptiste M, \& Lyoussi B. (2000). Experimental diuretic activity of Rosmarinus officinalis and Centarium erythraea. Journal of Ethnopharmacology, 71: 465-472. http://dx.doi.org/10.1016/S0378-8741(00)00184-7

Harnafi H, Bouanani NH, Aziz M, Caid HS, Ghalim N, \& Amrani S. (2007). The hypolipidaemic activity of aqueous Erica multiflora flowers extract in Triton WR-1339 induced hyperlipidaemic rats: A comparison with fenofibrate. Journal of Ethnopharmacology, 109: 156-160. http://dx.doi.org/10.1016/j.jep.2006.09.017

Hou FX, Yang HF, Yu T, \& Chen W. (2007). The immunosuppressive effects of $10 \mathrm{mg} / \mathrm{kg}$ cyclophosphamide in Wistar rats. Enviromental Toxicology and Pharmacology, 24 (1): 30-36. http://dx.doi.org/10.1016/j.etap.2007.01.004

Hudson L, \& Hay FC. (1989). Practical immunology. 3rd ed. Blakwell Scientific Puplications. London.

Kaliora AC \& Andrikopoulos NK. (2005). Effect of Alkanna albugam root on LDL oxidation. A comparative study with species of the Lamiaceae family. Phytotherapy Research, 19: 1077-1079. http://dx.doi.org/10.1002/ptr.1774

Lee J, Chae K, Ha J, Byung-Young P, Lee HS, Jeong S, Min-Young K, \& Yoon M. (2008). Regulation of obesity and lipid disorders by herbal extracts from Morus alba, Melissa officinalis, and Artemisia capillaris in high-fat diet-induced obese mice. Journal of Ethnopharmacology, 115: 263- 270. http://dx.doi.org/10.1016/j.jep.2007.09.029

Lemonica IP, Damasceno DC, \& di-Stasi LC. (1996). Study of the embryotoxic effects of an extracts of rosemary (Rosmarinus officinalis L.). Brazilian Journal of Medical and Biological Research, 29 (2): 223-227.

Liddell JE \& Cryer A. (1991). A practical guide to monoclonal antibodies. John Wilely \& Sons, Chichester.

Lo AH, Liang YC, Shiau SYL, Ho CT, \& Lin JK. (2002). Carnosol, an antioxidant in rosemary, suppresses inducible nitric oxide synthase through down-regulation nuclear factor kappa B in mouse macrophages. Carcinogenesis, 3 (6): 983-991. http://dx.doi.org/10.1093/carcin/23.6.983

Luis JC, Perez RM, \& Gonzales FV. (2007). UV-B radiation effects on foliar concentrations of rosmarinic and carnosic acids in rosemary plants. Food Chemistry, 101: 1211-1215. http://dx.doi.org/10.1016/j.foodchem.2006.03.023 
Marin M, Koko V, Duletic-Lausevic S, Marin PD, Rancic D, \& Dajic-Stevanovic Z. (2006). Glandular trichomes on the leaves of Rosmarinus officinalis: morphology, stereology and histochemistry. South African Journal of Botany, 72: 378-382. http://dx.doi.org/10.1016/j.sajb.2005.10.009

Martinez J, Tomas G, Merino S, Arriero E, \& Moreno J. (2003). Detection of serum immunoglobulins in wild birds by direct ELISA: a methodological study to validate the technique in different species using antichicken antibodies. Functional Ecology, 17: 700-706. http://dx.doi.org/10.1046/j.1365-2435.2003.00771.x

Marzouk Z, Mansour HB, Chraief I, Mosrati R, Cheriaa J, Neffati A, Marzouk B, Sfari M, Boukef K, Barillies D, \& Ghedira LC. (2006). Chemical composition, antibacterial and antimutagenic activities of four populations of Rosmarinus officinalis L. oils from Tunisia. Journal of Food, Agriculture and Environment, 4 (2): \& 89-94.

Miliauskas G, Mulder E, Linssen JPH, Beek TAV, \& Venskutonis PR. (2007). Evaluation of antioxidative properties of Germanium macrorrhizum and Potentilla fructicosa extracts in Dutch style fermented sausages. Meat Science, 77: 703-708. http://dx.doi.org/10.1016/j.meatsci.2007.05.026

Moreira MR, Ponce AG, dell Valle CE, \& Roura SI. (2005). Inhibitory parameters of essential oils to reduce a foodborne pathogen. LWT, 38: 565-570. http://dx.doi.org/10.1016/j.lwt.2004.07.012

Ninomiya K, Matsuda H, Shimoda H, Nishida N, Kasajima N, Yoshino T, Morikawa T, \& Yoshikawa M. (2004). Carnosic acid, a new class of lipid absorption inhibitor from sage. Bioorganic and Medicinal Chemistry Letters, $14 \quad$ (8): $1943-1946$. http://dx.doi.org/10.1016/j.bmcl.2004.01.091

Olaleye MT \& Rocha BTJ. (2008). Acetaminophen-induced liver damage in mice: effects of some medicinal plants on the oxidative defense system. Experimental and Toxicologic Pathology, 59: 319-327. http://dx.doi.org/10.1016/j.etp.2007.10.003

Oluwatuyi M, Kaatz GW, \& Gibbons S. (2004). Antibacterial and resistance modifying activity of Rosmarinus officinalis. Phytochemistry, $65 \quad$ (24): $3249-3254$. http://dx.doi.org/10.1016/j.phytochem.2004.10.009

Orhan I, Aslan S, Kartal M, Sener B, \& Baser KHC. (2008). Inhibitory effect of Turkish Rosmarinus officinalis L. on acetylcholinesterase and butyrylcholinesterase enzymes. Food Chemistry, 108: 663-668. http://dx.doi.org/10.1016/j.foodchem.2007.11.023

Ozcan MM, Unver A, Ucar T, \& Arslan D. (2008). Mineral content of some herbs and herbal teas by infusion and decoction. Food Chemistery, 106: 1120-1127. http://dx.doi.org/10.1016/j.foodchem.2007.07.042

Perez MB, Calderon NL, \& Croci CA. (2007). Radiation-induced enhancement of antioxidant activity in extracts of rosemary (Rosmarinus officinalis L.). Food Chemistry, 104: 585-592. http://dx.doi.org/10.1016/j.foodchem.2006.12.009 
Quan FS, Compans RW, Cho YK, \& Kang SM. (2007). Ginseng and Salviae herbs play a role as immune activators and modulate immune responses during influenza virus infection. Vaccine, 25 (2): 272-282. http://dx.doi.org/10.1016/j.vaccine.2006.07.041

Quing-Feng L, Sun L, Jian-Yong S, \& Di-Hua C. (2008). Hypocholesterolemic effect of stilbenes containing extract-fraction from Cajanus cajan L. on diet-induced $\begin{array}{lll}\text { hypercholesterolemia in mice. } & \text { Phytomedicine, } & \text { 15: }\end{array}$ http://dx.doi.org/10.1016/j.phymed.2008.03.002

Rui-Li Y, Li W, Yong-Hui S, \& Guo-Wei L. (2008). Lipoic acid prevents high-fat diet-induced dyslipidemia and oxidative stress: a microarray analysis. Nutrition, 24: 582-588. http://dx.doi.org/10.1016/j.nut.2008.02.002

Sahu A, Rawal N, \& Pangburn MK. (1999). Inhibition of complement by covalent attachment of rosmarnic acid to activated C3b. Biochemical Pharmacology, 57: 1439-1446. http://dx.doi.org/10.1016/S0006-2952(99)00044-1

Sancheti G \& Goyal PK. (2006). Effect of Rosmarinus officinalis in modulating 7,12-dimethylbenz(a)anthracene induced skin tumorigenesis in mice. Phytotherapy Research, 20: 981-986. http://dx.doi.org/10.1002/ptr.1989

Sharma B, Viswanth G, Salunke R, \& Roy P. (2008). Effects of flavonoid-rich extract from seeds of Eugenia jambolana L. on carbohydrate and lipid metabolism in diabetic mice. Food Chemistry, 110: 697-705. http://dx.doi.org/10.1016/j.foodchem.2008.02.068

Smits JEG \& Baos R. (2005). Evaluation of the antibody mediated immune response in nestling American kestrels (Falco sparverius). Developmental and Comparative Immunology, 29: 161-170. http://dx.doi.org/10.1016/j.dci.2004.06.007

Sotelo-Felix JI, Martinez-Fong D, Muriel P, Santillan RL, Castillo D, \& Yahuaca P. (2002). Evaluation of the effectiveness of Rosmarinus officinalis (Lamiaceae) in the alleviation of carbon tetrachloride-induced acute hepatotoxicity in the rat. Journal of Ethnopharmacology, 81: 145-154. http://dx.doi.org/10.1016/S0378-8741(02)00090-9

Soyal D, Jindal A, Singh I, \& Goyal PK. (2007). Modulation of radiation-induced biochemical alterations in mice by rosemary (Rosmarinus officinalis) extract. Phytomedicine, 14 (10): 701-705. http://dx.doi.org/10.1016/j.phymed.2006.12.011

Tawaha K, Alali FQ, Gharaibeh M, Mohammad M, \& El-Elimat T. (2007). Antioxidant activity and total phenolic content of selected Jordanian plant species. Food Chemistry, 104: 1372-1378. http://dx.doi.org/10.1016/j.foodchem.2007.01.064

Uehara Y, Urata Y, Ideishi M, Arakawa K, \& Saku K. (2002). Chymase inhibition suppresses high-cholesterol diet-induced lipid accumulation in the hamster aorta. Cardiovascular Research, 55: 870-876. http://dx.doi.org/10.1016/S0008-6363(02)00458-3

Wang W, Wu N, Zu YG, \& Fu YJ. (2008). Antioxidative activity of Rosmarinus officinalis L. essential oil compared to its main components. Food Chemistry, 108: 1019-1022. http://dx.doi.org/10.1016/j.foodchem.2007.11.046 
Weckessera S, Engela K, Simon-Haarhausa B, Wittmerb A, Plezb K, \& Schempp CM. (2007). Screening of plant extracts for antimicrobial activity against bacteria and yeasts with $\begin{array}{llll}\text { dermatological } & \text { relevance. } & \text { Phytomedicine, } & \text { 508-516. }\end{array}$ http://dx.doi.org/10.1016/j.phymed.2006.12.013

Wellwood CRL \& Cole RA. (2004). Relevance of carnosic acid concentrations to the selection of rosemary, Rosmarinus officinalis (L.), accessions for optimization of ntioxidant yield. Journal of Agricultural and Food Chemistry, 52: 6101-6107. http://dx.doi.org/10.1021/jf035335p

Xiao-Ming W, Ying-Li Z, Xin-Min L, Shun-Xing G, \& Wang H. (2006). Immune responses in mice to arecoline mediated by lymphocyte muscarinic acetylcholine receptor. Cell Biology International, 30 (12): 1048-1053. http://dx.doi.org/10.1016/j.cellbi.2006.09.015

Zaouali Y \& Boussaid M. (2008). Isozyme markers and volatiles in Tunisian Rosmarinus officinalis L. (Lamiaceae): A comparative analysis of population structure. Biochemical Systematic and Ecology, 36: 11-21. http://dx.doi.org/10.1016/j.bse.2007.08.005

\section{Copyright Disclaimer}

Copyright reserved by the author(s).

This article is an open-access article distributed under the terms and conditions of the Creative Commons Attribution license (http://creativecommons.org/licenses/by/3.0/). 